\title{
NERVE GROWTH FACTOR-INDUCED INCREASE IN SAXITOXIN BINDING TO RAT PC12 PHEOCHROMOCYTOMA CELLS ${ }^{1}$
}

\author{
B. RUDY, B. KIRSCHENBAUM, AND L. A. GREENE
}

Departments of Physiology and Pharmacology, New York University Medical School, New York, New York 10016

Received February 23, 1982; Revised May 17, 1982; Accepted May 17, 1982

\begin{abstract}
The PC12 clone is a line of rat pheochromocytoma cells which undergoes neuronal differentiation in the presence of nerve growth factor (NGF) protein. In the absence of NGF, PC12 cells are electrically inexcitable, while after several weeks of NGF treatment, they develop sodium action potentials. The number and density of sodium channels on PC12 cells before and after treatment with NGF were estimated by measuring the binding of $\left[{ }^{3} \mathrm{H}\right]$ saxitoxin $\left(\left[{ }^{3} \mathrm{H}\right] \mathrm{STX}\right)$. The data indicate that $\left.{ }^{3} \mathrm{H}\right] \mathrm{STX}$ binding increases in the NGF-treated cells by 15 - to 20 -fold per cell, 3 - to 10 -fold per $\mathrm{mg}$ of protein, and an estimated 7 -fold per unit area of membrane. The kinetic properties for $\left[{ }^{3} \mathrm{H}\right]$ STX binding are unchanged, however, by NGF treatment. A Hodgkin-Huxley analysis (Hodgkin, A. L., and A. F. Huxley (1952) J. Physiol. (Lond.) 117: 500-544) suggests that the estimated density of sodium channels in NGF-untreated PC12 cells is sufficient to explain their lack of excitability. On the other hand, the estimated channel density on the NGF-treated cells ( 30 to $\left.50 / \mu \mathrm{m}^{2}\right)$ is comparable to that in other excitable systems. Thus, the development of excitability in PC12 cells in response to NGF could be due to the induction of sodium channel synthesis.
\end{abstract}

The PC12 clonal cell line of rat pheochromocytoma cells undergoes a neuron-like morphological and physiological differentiation in the presence of nerve growth factor (NGF) protein (Greene and Tischler, 1976; Dichter et al., 1977). This system may serve as a model for the events that occur during the development and maturation of the normal nervous system. When grown in the presence of NGF, PC12 cells cease to divide, extend long neurite-like processes, and become excitable (i.e., they develop a tetrodotoxin ('TTX)-sensitive $\mathrm{Na}^{+}$action potential). PC12 cells grown in the absence of NGF are not excitable (Dichter et al., 1977) and show only a tetraethylammonium (TEA)-sensitive delayed rectification in intracellular electrical recordings (O'Lague and Huttner, 1980). However, in spite of being nonexcitable, PC12 cells grown in the absence of NGF seem to contain at least some sodium channels since veratridine, an alkaloid which activates sodium channels (Ulbricht, 1969; Catter-

\footnotetext{
${ }^{1}$ This research was supported in part by United States Public Health Service Research Grants GM 26976 to B. R. and NS 16036 to L. A. G. and a March of Dimes Birth Defects Foundation Research Grant to L. A. G. We thank Dr. Adriana Rukenstein for her invaluable assistance with the cell culture, Dr. Y. Yarom for his assistance in setting up the electrophysiology apparatus, and Dr. G. Strichartz for his gift of labeled saxitoxin.

${ }^{z}$ To whom correspondence should be addressed at Department of Physiology and Biophysics, New York University Medical Center, 550 First Avenue, New York, NY 10016.
}

all, 1975), stimulates the release of endogenous catecholamine stores (Greene and Rein, 1977). The lack of sodium action potentials in NGF-untreated PC12 cells thus could result from particular passive properties of their cell membranes, from too low a density of sodium channels, from the presence of modified sodium channels capable of responding to veratridine but incapable of responding to the membrane potential appropriately, or from a combination of the above.

A better understanding of the permeability properties of PC12 cells and the development of excitability induced by NGF could be obtained from a combination of electrical and pharmacological studies. This, in turn, may lead to insight as to the mechanism by which neurons acquire excitable properties during normal development. Here, we report on the binding to NGF-treated and -untreated PC12 cells of saxitoxin (STX), a neurotoxin which is known to bind specifically to the sodium channel (Henderson et al., 1973) at the same site as TTX.

\section{Materials and Methods}

Materials. Chemicals were obtained from the following sources: tetrodotoxin and Triton X-100 from Sigma, Aquasol from New England Nuclear, and choline chloride from Eastman. All other chemicals were reagent grade. Millipore Super Q purified water was used throughout. $\left[{ }^{3} \mathrm{H}\right] \mathrm{STX}$ was generously provided by Dr. G. Strichartz, State University of New York at Stony Brook. 
Culture of cells. $\mathrm{PC} 12$ cells were grown as previously described (Greene and Tischler, 1976; Dichter et al., 1977) in either multiwell (for binding studies) or 35- $\mathrm{mm}$ (for electrophysiology) dishes coated with rat tail collagen or with polyornithine (Letourneau, 1975). 2.5 S NGF (Bocchini and Angeletti, 1969) was added to some cultures at a final concentration of $50 \mathrm{ng} / \mathrm{ml}$. Exposure to $\mathrm{NGF}$ was for at least 2 weeks in all experiments. In some experiments, cells were grown in suspension by placing them in plastic Petri dishes (Falcon). The cells do not attach to this substrate and, in the presence of NGF, cannot produce neurites.

Estimation of cell membrane area. The cell membrane area was estimated as follows: cells were detached from the substrate mechanically and replated into plastic dishes. When the cells settled to the bottom of the dish but before they altached, they exhibited round, approximately spherical, shapes. The diameter of the cells was determined by means of an eyepiece micrometer fitted to an inverted phase microscope $(\times 400)$. At least 17 consecutive random cells were scored. The cell surface area was calculated on the assumption that the unattached rounded cells approximated spheres.

Characterization of $\left[^{3} \mathrm{H}\right] \mathrm{STX}$. Tritiated saxitoxin was a kind gift of Dr. G. Strichartz and was prepared by the specific ${ }^{3} \mathrm{H}-\mathrm{H}_{2} \mathrm{O}$ exchange procedure of Ritchie et al. (1976). Its specific activity was $10 \mathrm{Ci} / \mathrm{mmol}$. The saxitoxin was stored in small aliquots in $10 \mathrm{mM}$ MES (2- $(N$-morpholino) ethanesulfonic acid), $\mathrm{pH} 6.5$, at $-70^{\circ} \mathrm{C}$.

The radiochemical purity of $\left[{ }^{3} \mathrm{H}\right]$ saxitoxin was determined each experimental day by measuring the proportion of radioactivity bound by a membrane fraction from the electric organ of Electrophorus electricus (Agnew et al., 1978). Increasing amounts of membranes were incubated for $15 \mathrm{~min}$ at $4^{\circ} \mathrm{C}$ with a small aliquot of $\left[{ }^{3} \mathrm{H}\right] \mathrm{STX}$ (approximately $5 \mathrm{nM}$ ). The samples then were centrifuged at $100,000 \times g$ for $15 \mathrm{~min}$ and the radioactivity remaining in the supernatant was measured by scintillation in Aquasol. The radioactivity remaining in the supernatant decreased asymptotically as the amount of membranes increased up to a maximum from which the purity of STX was determined. This remaining fraction ranged from 25 to $45 \%$ of the ${ }^{3} \mathrm{H}$ and represents impurities in the $\left[{ }^{3} \mathrm{H}\right] \mathrm{STX}$ (Ritchie et al., 1976; Krueger et al., 1979). All data were corrected for the radiochemical purity. As found previously (Krueger et al., 1979), the radioactivity bound by the membranes could be competed off quantitatively by incubating the membranes in presence of unlabeled TTX, thus verifying that the ${ }^{3} \mathrm{H}$ bound represents $\left[{ }^{3} \mathrm{H}\right] \mathrm{STX}$.

Saxitoxin binding assay. Saxitoxin binding was measured essentially by the method of Catterall and Morrow (1978). The culture media were removed gently by suction and replaced with 1 ml of a solution containing 130 $\mathrm{mM}$ choline chloride, $5.4 \mathrm{mM} \mathrm{KCl}, 0.8 \mathrm{mM} \mathrm{MgCl}_{2}, 5.5 \mathrm{~mm}$ glucose, $50 \mathrm{~mm}$ Tris/HEPES, $\mathrm{pH} 7.4$, various concentrations of $\left[{ }^{3} \mathrm{H}\right] \mathrm{STX}$ (ranging from 0 to $20 \mathrm{nM}$ ), and on occasion, TTX (usually at a concentration of $1 \mu \mathrm{M}$ ). The cells were incubated in this solution under continuous gentle shaking at $34^{\circ} \mathrm{C}$ for $30 \mathrm{~min}$ to assure that equilibrium was completed.
At the end of the incubation, the unbound $\left[^{3} \mathrm{H}\right] \mathrm{S} / \mathrm{IX}$ was removed by quickly washing three times at $0^{\circ} \mathrm{C}$ with $3 \mathrm{ml}$ of a solution containing $163 \mathrm{~mm}$ choline chloride, 1.8 $\mathrm{mm} \mathrm{CaCl}, 0.8 \mathrm{mM} \mathrm{MgCl}_{2}$, and $5 \mathrm{~mm}$ Tris/HEPES $(\mathrm{pH}$ 7.4). The three washes required 8 to 10 sec except for those in the experiments to determine washout rates (see below).

After completion of the experiment, the cells were dissolved in $1 \mathrm{ml}$ of $0.5 \%$ Triton X-100 and the wells were washed with an extra $1 \mathrm{ml}$ of the Triton X-100 solution. Aquasol was added to the pooled Triton X-100 extracts. The vials were stored in the dark to allow for the decay of phosphorescence and counted by scintillation counting. Each experimental point is the average of six identical experiments. The number of cells and the amount of cell protein in each well were determined in sister dishes prepared simultaneously and treated as above. Cells were quantified by counting the nuclei in a hemacytometer after release with $0.2 \%$ Triton X-100. Protein was determined by the Lowry method (Lowry et al., 1951).

Intracellular recordings. For intracellular recordings, PC12 cells were grown in 35-mm collagen-coated Falcon plastic tissue culture dishes as described by Greene and Tischler (1976). Recordings were performed at $30^{\circ} \mathrm{C}$. Immediately before the experiment, the culture medium was removed gently and replaced by a solution containing $6 \mathrm{~mm}$ glucose, $140 \mathrm{~mm} \mathrm{NaCl}, 3 \mathrm{~mm} \mathrm{KCl}, 1.8 \mathrm{~mm} \mathrm{CaCl}_{2}$, and $1.0 \mathrm{~mm} \mathrm{MgCl}_{2}$ and buffered to $\mathrm{pH} 7.4$ by $2.5 \mathrm{~mm}$ phosphate or Tris buffer. The cultures were placed on the stage of an inverted phase contrast microscope on an air table. The cells were impaled under direct vision with microelectrodes backfilled with $3.5 \mathrm{M}$ potassium acetate ( $R=40$ to 70 megohms). Current was injected through the recording electrode using a Neuro Data Instruments Corp. bridge amplifier with $\times 10$ amplification on the voltage recording. Signals were recorded on a Tektronix 5115 oscilloscope and photographed.

\section{Results}

Electrical properties of $\mathrm{PC} 12$ cells. The resting potentials of PC12 cells grown in the presence or absence of NGF ranged from -35 to $-60 \mathrm{mV}$. No significant differences were found whether the cells were grown in the presence or absence of NGF.

The response of PC12 cells to electrical stimulation did depend on whether the cells were grown with NGF. Figure 1 illustrates the recordings of the membrane potential in response to square current pulses injected through the microelectrodes. Regardless of the growth conditions, membrane resistance decreased with depolarization. However, only cells grown with $\mathrm{NGF}\left(\mathrm{NGF}^{+}\right)$ gave action potentials above threshold. The action potentials could be blocked by $300 \mathrm{~nm}$ TTX. Cells grown in the absence of NGF $\left(\mathrm{NGF}^{-}\right)$showed only a delayed rectification, most of which was blocked by 20 mM TEA. Action potentials in $\mathrm{NGF}^{-}$cells could not be shown in the presence of $20 \mathrm{~mm}$ TEA or even if the depolarizing current was preceded by hyperpolarization to -80 or $-100 \mathrm{mV}$ for periods of up to $5 \mathrm{~min}$. These results confirm those obtained by Dichter et al. (1977) and those of 
O'Lague and Huttner (1980) with larger PC12 cell heterokaryons obtained by fusion.

$\mathrm{NGF}^{+}$cells were excitable even in the absence of neurites. The action potentials shown on Figure $1 B$ were obtained from PC12 cells grown in the presence of NGF in collagen-coated dishes for 3 weeks and then resuspended and replated on polyornithine-coated dishes in the presence of NGF for $24 \mathrm{hr}$. Upon detachment under these conditions, the cells lose their neurites due to mechanical shearing (Greene, 1977). While such cells rapidly regenerate their neurites when plated on a collagen-coated substrate, when the cells are replated on polyornithine-coated dishes, neurite regrowth is considerably slowed down. After $24 \mathrm{hr}$ on polyornithine, only very few of the cells show neurites.

Also, action potentials were present in $\mathrm{PC} 12$ cells which were exposed to NGF for 2 weeks in suspension culture and then assayed for excitability after being allowed to attach to a polyornithine substrate for 4 to 5 hr. In this case, neurites were absent both in suspension and after attachment. As will be discussed below, the absence of neurites on such cells enables calculation of the membrane area.

From records such as those in Figure 1, current-voltage curves were drawn and the membrane resistance was calculated from the linear hyperpolarizing part of the curve. Input resistance ranged from 20 to 100 megohms in $\mathrm{NGF}^{+}$cells. For cells grown on polyornithine, the membrane area can be estimated even after NGF treatment because neurite outgrowth is slowed down. The membrane resistance thus was estimated to range between 180 and $900 \mathrm{ohm} \mathrm{cm}^{2}$. Cells grown in the absence of NGF on polyornithine show similar input resistances in spite of having about half of the membrane area as $\mathrm{NGF}^{+}$cells. Although more damage is expected to result from microelectrode penetration of $\mathrm{NGF}^{-}$cells due to their smaller size, these results suggest that the membrane resistance is, at best, the same as in $\mathrm{NGF}^{+}$cells.

Binding of $\left[{ }^{3} \mathrm{H}\right] \mathrm{STX}$ to PC12 cells. Figure 2 illustrates the total binding of $\left[{ }^{3} \mathrm{H}\right] \mathrm{STX}$ to $\mathrm{PC} 12$ cell cultures incubated with increasing concentrations of $\left[{ }^{3} \mathrm{H}\right] \mathrm{STX}$. The profile of binding suggests the presence of both saturable and nonsaturable components ( $\square$ ). When the cells are incubated in the presence of $1 \mu \mathrm{M}$ TTX, only a linear, nonsaturable binding is observed ( $\bullet$ ). It usually is assumed that, at this concentration of TTX, the receptor sites for STX are fully saturated, and thus, the linear binding is thought to represent nonspecific absorption of $\left[{ }^{3} \mathrm{H}\right]$ STX. The difference between the total binding and nonspecific binding thus represents specific binding $(\mathbf{\Lambda})$. The specific binding component is plotted as a Scatchard plot in Figure 3. A straight line was obtained in the Scatchard plots, indicating the presence of a single class of saturable binding sites. For the experiment shown in Figure 2, an apparent $K_{d}$ of $2.7 \mathrm{nM}$ and a binding capacity of 2,800 sites/cell were obtained from the Scatchard plot (Fig. 3). The mean values \pm SEM from three experiments were $3.0 \pm 0.3 \mathrm{nM}$ for the apparent $K_{d}$ and 2,500 \pm 760 for the number of binding sites.

The Scatchard plot for an experiment with $\mathrm{NGF}^{+}$cells also is shown in Figure 3. In this experiment, an apparent
$K_{d}$ of $2.5 \mathrm{~nm}$ was obtained. The number of binding sites was $60,000 /$ cell. The mean values from two experiments were $3.0 \pm 0.5 \mathrm{~nm}$ and 61,300 sites/cell for the $K_{d}$ and number of binding sites, respectively.

We also have compared the off rate for the interaction of $\left[{ }^{3} \mathrm{H}\right] \mathrm{STX}$ with its receptor. Cells were incubated with $10 \mathrm{nM}\left[{ }^{3} \mathrm{H}\right]$ STX as described under "Materials and Methods" but washed at $0^{\circ} \mathrm{C}$ for different periods of time. The specific binding estimated as above was plotted on a semilogarithmic scale against time. A straight line was obtained from which an average apparent off rate constant of $0.0079 \mathrm{sec}^{-1}$ was obtained from three experiments with $\mathrm{NGF}^{-}$cells and $0.0062 \mathrm{sec}^{-1}$ from two experiments with $\mathrm{NGF}^{+}$cells. The constants yield average half-times of washout of 88 and $112 \mathrm{sec}$ for $\mathrm{NGF}^{-}$and $\mathrm{NGF}^{+}$celis, respectively. Since the washing time for our binding experiments ( 8 to $10 \mathrm{sec}$ ) was much less than the half-times for washout, the number of binding sites determined from the Scatchard plots must be close to the true number of binding sites.

Density of $\left[{ }^{3} H\right] S T X$ receptors. The data shown above demonstrate that incubation with NGF increases by 30 fold the number of STX receptors on PC12 cells. However, $\mathrm{NGF}^{+}$cells are larger and possess long processes, and thus, the number of binding sites per cell does not reflect the density of the sites. The membrane area is difficult to estimate in $\mathrm{NGF}^{+}$cells since the cell body is not rounded and the cells contain various numbers of processes of various lengths and diameters. The density of the sites in $\mathrm{NGF}^{-}$cells can be more readily calculated because the cells are round and lack processes. Estimates of receptor density for $\mathrm{NGF}^{-}$cells growing on a collagen substrate are given in Table $\mathrm{I}$.

In order to estimate the density of receptors on $\mathrm{NGF}^{+}$ cells, two strategies were employed. First, cells were grown in the presence of NGF in collagen-coated dishes and then resuspended, replated on polyornithine-coated dishes, and incubated in the presence of NGF for an additional $24 \mathrm{hr}$. As described above, these cells lack neurites, and hence, the membrane area can be readily estimated. $\left[{ }^{3} \mathrm{H}\right] \mathrm{S}$ TX binding was studied with these cells as well as with $\mathrm{NGF}^{-}$cells also replated from collagen-coated dishes onto polyornithine. The results of these studies are shown in Table I. The number of receptors and the density of receptors on such $\mathrm{NGF}^{-}$ cells was similar to that for $\mathrm{NGF}^{-}$cells plated on collagen-coated dishes. Although the number of receptors per cell in $\mathrm{NGF}^{+}$cultures was somewhat less (about $75 \%$ ) than that found for $\mathrm{NGF}^{+}$cells grown on collagen, it was substantially greater than that found on $\mathrm{NGF}^{-}$cells. The densities of receptors were calculated and the results are shown in Table I. Comparison of the receptor density on $\mathrm{NGF}^{+}$cells and $\mathrm{NGF}^{-}$cells shows that incubation in the presence of NGF results in a 6.5 -fold increase in the average density of receptors on the cell surface. As mentioned above, cells grown in these conditions maintain the same electrical properties as those grown on collagen; that is, only cells grown in the presence of NGF were excitable (Fig. 1).

Table I also shows data for a second strategy by which the cells were exposed to NGF under conditions in which 

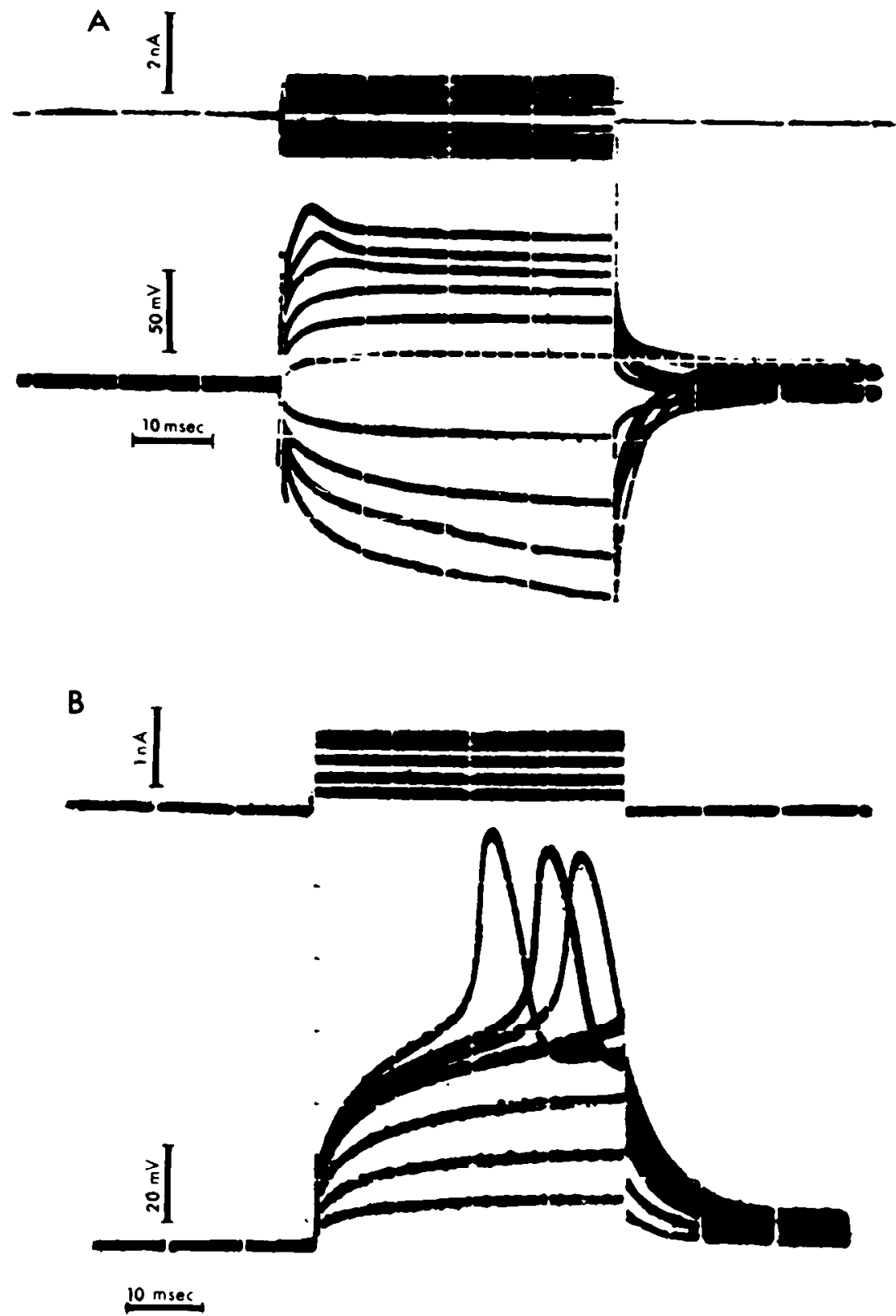

Figure 1. Electrical responses of PC12 cells. A, PC12 cells were grown on collagen-coated dishes in the absence of NGF and then resuspended, replated on polyornithine-coated dishes, and incubated for $24 \mathrm{hr}$ in the absence of NGF. Intracellular recording was as described under "Materials and Methods." The records shown are typical for such cultures as well as for cultures grown on collagen for up to several weeks and not passaged. The cell from which the records were taken had a resting potential of -42 $\mathrm{mV}$. The cell was hyperpolarized to $-80 \mathrm{mV}$ for $5 \mathrm{~min}$ and current pulses then were applied from this potential at $1-\mathrm{min}$ intervals. The membrane potential in response to the applied current pulses (upper traces) is shown in the lower traces. Six depolarizing pulses and four hyperpolarizing pulses are superimposed. Delayed rectification is seen in the three larger depolarizing responses. $B$, Records from a culture incubated in the presence of NGF for 3 weeks on collagen-coated dishes, resuspended to shear off neurites, and then cultured for $24 \mathrm{hr}$ on polyornithine dishes in the presence of NGF. Seven superimposed voltage responses (lower traces) to depolarizing square current pulses (upper traces) are shown for a single cell. The resting potential was -50 $\mathrm{mV}$. The cell was hyperpolarized to $-80 \mathrm{mV}$ for $5 \mathrm{~min}$ and current pulses then were applied from this potential at 1-min intervals. Depolarizing pulses evoke an action potential above threshold. Similar responses were obtained from other cells in such cultures as well as from NGF-treated cultures that had not been passaged onto polyornithine.

the surface area and $\left[{ }^{3} \mathrm{H}\right] \mathrm{STX}$ binding could be estimated. The cells were grown in suspension in the presence or absence of NGF for 2 weeks. Under these conditions, $\mathrm{NGF}^{+}$cells do not form neurites but undergo a variety of responses to NGF (Greene and Tischler, 1981). The cells then were plated on polyornithine dishes, al- lowed sufficient time ( 4 to $5 \mathrm{hr}$ ) to attach, and subjected to binding experiments as well as cell surface estimation. The data shown are for two experiments with each type of cell. For both $\mathrm{NGF}^{-}$and $\mathrm{NGF}^{+}$cells, the number of receptors per cell is less than that obtained on a collagencoated substrate. Nevertheless, NGF still induced a 6 - 


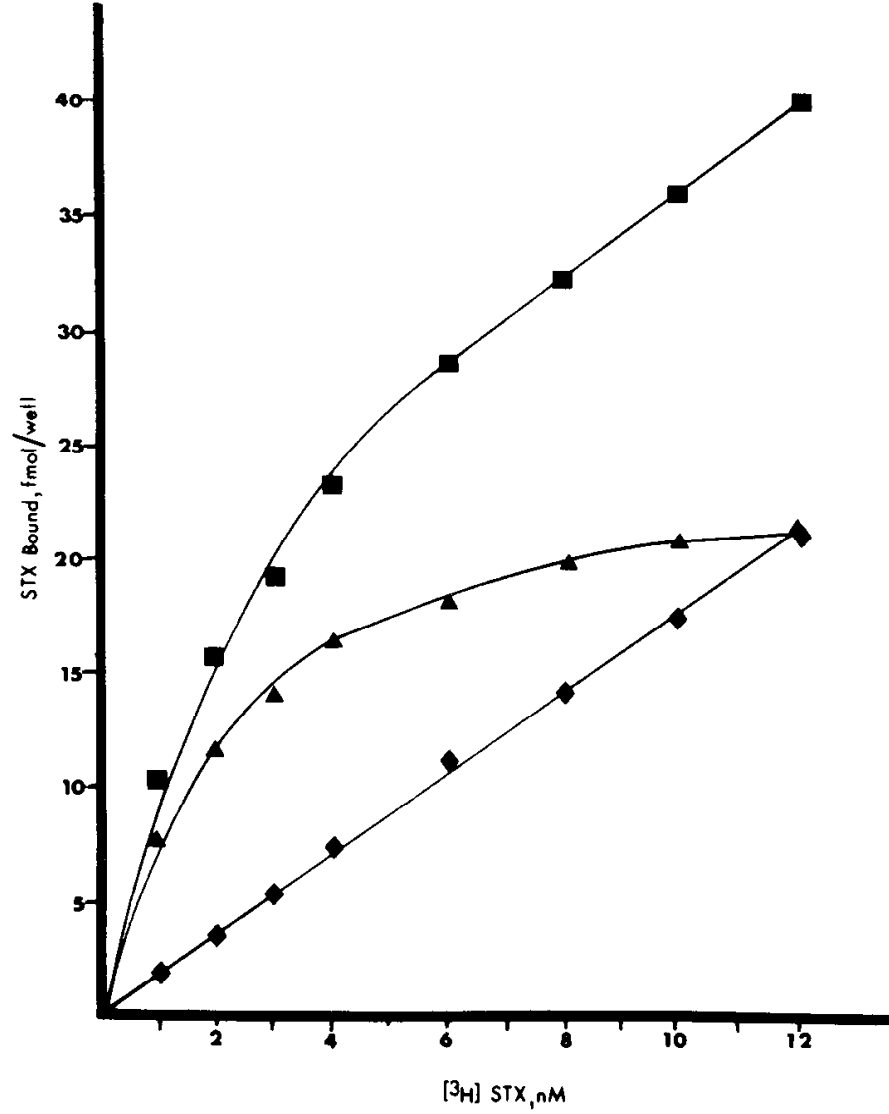

Figure 2. Binding of $\left[{ }^{3} \mathrm{H}\right] \mathrm{STX}$ to $\mathrm{PC} 12$ cell cultures. Cells were grown in collagen-coated multiwell dishes without NGF as described in the text. Cultures were incubated for $30 \mathrm{~min}$ at $34^{\circ} \mathrm{C}$ with the indicated concentrations of $\left[{ }^{3} \mathrm{H}\right] \mathrm{STX}$ alone $(\square)$ or in the presence of $1 \mu \mathrm{M}$ TTX $(\diamond)$, and the amount of $\left[{ }^{3} \mathrm{H}\right]$ STX bound was estimated as described undér "Materials and Methods." $\Delta$, The points obtained after subtracting the nonspecific binding $(\downarrow)$ from the total binding $(\square)$. The curves were drawn by hand (experiment 4-N-80). Each well contained 1.4 $\times 10^{6}$ cells.

fold increase in the density of receptors. As described above, electrical studies revealed that $\mathrm{NGF}^{+}$cells in these conditions were also excitable, while $\mathrm{NGF}^{-}$cells were not.

\section{Discussion}

PC12 cells have too few sodium channels to be excitable. Studies of TTX and STX binding to various excitable tissues have revealed a large variation in the density of receptors. These range from several hundred per $\mu \mathrm{m}^{2}$ in the giant axons of Loligo to 25 to 30 per $\mu \mathrm{m}^{2}$ in small nonmyelinated nerve fibers (Ritchie and Rogart, 1977). In myelinated nerves, a high density of STX receptors is found on the excitable nodes of Ranvier $\left(12,000 / \mu \mathrm{m}^{2}\right)$, while they are not detectable on the internodal axolemma. Several lines of evidence suggest that there is one receptor per sodium channel (Cuervo and Adelman, 1970; Narahashi, 1974; Keynes et al., 1975), and hence, we can use the number of receptors as an estimate of the number of sodium channels.

Hodgkin (1975) has proposed that, as the number of

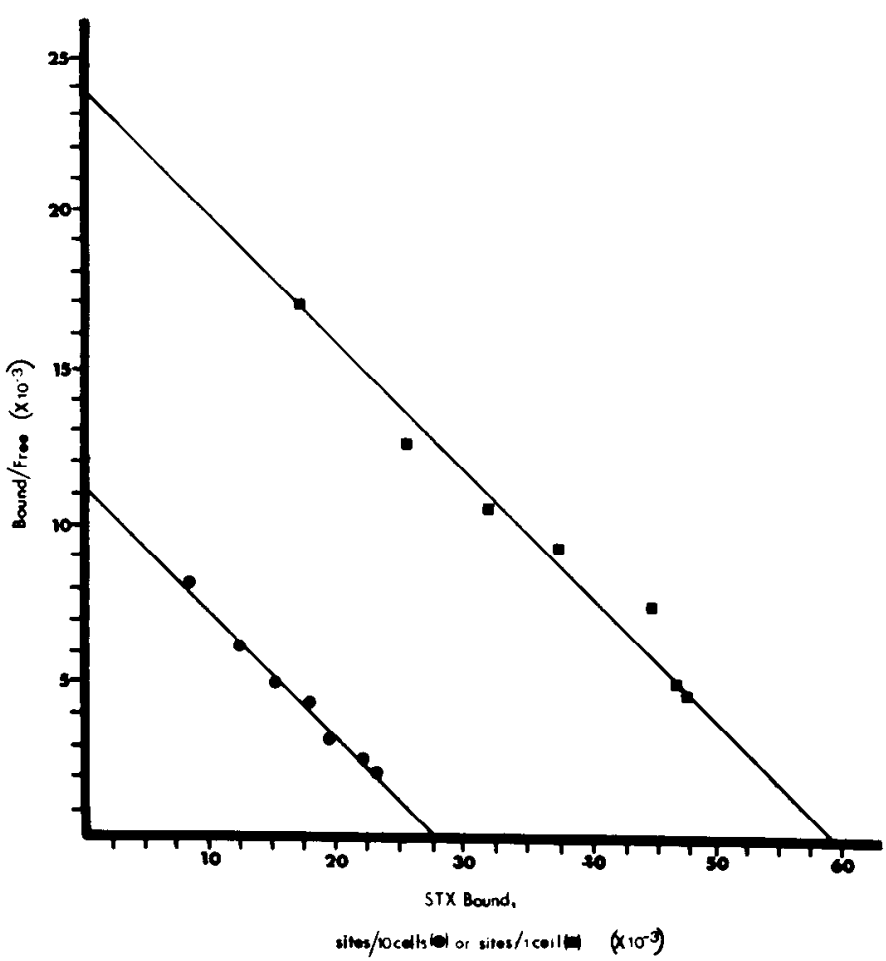

Figure 3. Scatchard plots of the specific (total - nonspecific) binding of $\left[{ }^{3} \mathrm{H}\right] \mathrm{STX}$ to PC12 cells. Data from the experiment shown in Figure 2. $\mathbf{0}$, Data from a similar experiment with NGF-treated cultures. Note that STX binding sites are expressed per 10 cells for the $\mathrm{NGF}^{-}$cells and per cell for the $\mathrm{NGF}^{+}$cells.

sodium channels increases in the membrane, two opposite factors contribute to determine the conduction velocity of a nerve impulse. As the number of channels increases, the net inward current available to depolarize the nerve increases. However, as the number of channels increases, the amount of capacitance to be charged also increases since the gating mechanism of the channel involves the movement of intramembrane charged particles. Thus, a maximum is predicted in the relation between sodium channel density and conduction velocity. This maximum has been estimated to be around several hundred channels per $\mu \mathrm{m}^{2}$ (Hodgkin, 1975; Adrian, 1975).

The average density of receptors in $\mathrm{NGF}^{-} \mathrm{PC} 12$ cells is lower than that found thus far in any excitable membrane. Since the membrane resistance of these cells is not larger than that of other excitable cells and it is unlikely that their capacitance is smaller, it seems that the low density of $\mathrm{Na}^{+}$channels is sufficient to explain the failure of electrical stimulation to generate action potentials in these cells. Assuming that the single channel conductance is similar to that in $\mathrm{Na}^{+}$channels in other excitable membranes (i.e., around $10 \mathrm{pS}$ ), inward sodium current would hardly be larger than the "leak" outward current which tends to repolarize the membrane. For example, at $-10 \mathrm{mV}$ where sodium current usually reaches a maximum (due to the opposing influences of the increased number of sodium channels that are activated upon depolarization and the driving force which decreases as the $\mathrm{Na}^{+}$equilibrium potential is approached), the value for inward sodium current can be calculated from the relationship: 
TABLE I

[3H]STX binding to PC12 cells

Saturation values were obtained from experiments using $13 \mathrm{nM}\left[{ }^{3} \mathrm{H}\right] \mathrm{STX}$.

\begin{tabular}{|c|c|c|c|c|c|}
\hline Culture Conditions $^{a}$ & $\begin{array}{l}\mathrm{Na}^{+} \text {Action } \\
\text { Potential }\end{array}$ & $n^{b}$ & $\begin{array}{c}\text { Specific } \\
{\left[{ }^{3} \mathrm{H}\right] \mathrm{STX}} \\
\text { Binding } \\
\pm \mathrm{SE}\end{array}$ & $\begin{array}{l}\text { STX Receptors } \\
\text { per Cell } \\
\pm \mathrm{SE}\end{array}$ & $\begin{array}{l}\text { Calculated } \\
\text { Average } \\
\text { Receptor } \\
\text { Density } \\
\pm \mathrm{SE}\end{array}$ \\
\hline \multicolumn{6}{|l|}{ Cells grown on collagen } \\
\hline$-\mathrm{NGF}$ & - & 4 & $26 \pm 6$ & $2,680 \pm 1,080$ & $7.73 \pm 2.2$ \\
\hline$+\mathrm{NGF}$ & + & 3 & $223 \pm 26$ & $53,861 \pm 7,509$ & \\
\hline \multicolumn{6}{|c|}{$\begin{array}{l}\text { Cells grown on collagen and passaged for } 24 \mathrm{hr} \\
\text { onto polyornithine }\end{array}$} \\
\hline$-\mathrm{NGF}$ & - & 3 & $47 \pm 22$ & $2,360 \pm 841$ & $7.45 \pm 2.9$ \\
\hline$+\mathrm{NGF}$ & + & 3 & $422 \pm 100$ & $44,670 \pm 1,002$ & $51 \pm 4$ \\
\hline \multicolumn{6}{|c|}{$\begin{array}{l}\text { Cells grown in suspension and plated on polyor- } \\
\text { nithine for } 4 \text { to } 5 \mathrm{hr}\end{array}$} \\
\hline
\end{tabular}

cells were exposed to NGF for at least 2 weeks prior to experimentation.

${ }^{b} n$, number of experiments.

$$
I_{\mathrm{Na}}=g_{\mathrm{ch}} \cdot N \cdot f\left(V-V_{\mathrm{Na}}\right)
$$

where $I_{\mathrm{Na}}$ is the maximum sodium current at voltage, $V$; $g_{c h}$ is the conductance for a single open channel; $N$ is the density of sodium channels in the membrane; $V-V_{\mathrm{Na}}$ is the driving force; and $f$ is the maximum fraction of sodium channels open at that potential. The latter value is derived from the product of the fraction of open activation gates $(0.8)$ at that $V$ and the fraction of "not closed" inactivation gates $(0.4)$ at the time that the current reaches a maximum (Hodgkin and Huxley, 1952). If $V_{\mathrm{Na}}$ (the $\mathrm{Na}^{+}$equilibrium potential) $=50 \mathrm{mV}$, at $V=-10 \mathrm{mV}$ :

$$
\begin{gathered}
I_{\mathrm{Na}}=10 \cdot 10^{-12} \mathrm{~S} / \text { channel } \times 8 \cdot 10^{8} \text { channels } / \mathrm{cm}^{2} \times 0.32 \times-60 \mathrm{mV} \\
I_{\mathrm{Na}}=154 \mu \mathrm{A} / \mathrm{cm}^{2}
\end{gathered}
$$

At the same potential, the leak current, $I_{L}$, will be equal to

$$
I_{L}=\left(V-V_{L}\right) / R=50 \mathrm{mV} / 400 \mathrm{ohm} \mathrm{cm}^{2}=125 \mu \Lambda / \mathrm{cm}^{2}
$$

\footnotetext{
${ }^{3}$ As first shown by Hodgkin and Huxley (1952), at a particular depolarizing voltage, the sodium current is transient. The sodium current first increases upon depolarization due to the opening of the activation gates of the sodium channel and then declines due to the closing of a second, slower process, the inactivation process. The maximum fraction of sodium channels with open activation gates increases with depolarization and is around 0 at $-60 \mathrm{mV}$ and about $100 \%$ at $10 \mathrm{mV}$. It is around $80 \%$ at $-10 \mathrm{mV}$. Sodium currents were plotted as a function of time from the numerical calculations of Hodgkin and Huxley's equations at $-10 \mathrm{mV}$ with and without inactivation. In the presence of inactivation, the sodium current reaches a peak at 0.5 msec. In the absence of inactivation, the sodium current increases with time and reaches a steady state value by $0.5 \mathrm{msec}$. The peak sodium current observed in the presence of inactivation is about $40 \%$ of the steady state current observed when inactivation is assumed to be absent. Although some differences are to be expected between $\mathrm{PC1} 2$ cells and squid axons, we believe that the value of the current will not be significantly higher unless there were significant differences (i.e., the single channel conductance in PC12 cells is much larger or the inactivation is much slower).
}

if $V_{L}$ (the "leak equilibrium potential") $=-60 \mathrm{mV}$ and if we assume an input resistance of 100 megohms and a membrane area of $400 \mu \mathrm{m}^{2}$ (as calculated for $\mathrm{NGF}^{-}$cells). The value for $I_{L}$ is even larger in most cells since input resistance is usually lower than 100 megohms.

$N G F$ and increased excitability. It has been shown that the increased excitability of PC12 cells upon incubation with NGF is not due to a difference in size (O'Lague and Huttner, 1980), nor is it a simple consequence of the presence of neurites (Dichter et al., 1977). On the other hand, the results presented here demonstrate an apparent 6- to 7-fold increase in the average density of STX receptors on the membrane of $\mathrm{PC} 12$ cells after incubation with NGF. This effect certainly could be sufficient to explain the increased excitability of the PC12 cells. The average density of receptors after incubation with NGF is similar to that observed by Catterall and Morrow (1978) in excitable neuroblastoma cells (i.e., 78 sites $\left./ \mu \mathrm{m}^{2}\right)$. It is also similar to that found in small nonmyelinated nerve fibers (i.e., $35 / \mu \mathrm{m}^{2}$ in garfish olfactory nerves; Ritchie and Rogart, 1977). The calculations shown above also support this possibility. While $I_{\mathrm{Na}}$ will increase severalfold in $\mathrm{NGF}^{+}$cells, due to the increase in channel density, $I_{L}$ actually might be smaller after NGF treatment due to the increase in membrane area and similar input resistances.

We do not know yet how the presence of NGF results in an increase in the number of STX receptors. The increase could result from an increased synthesis of sodium channels or from the appropriate coupling of components alrcady present in the membrane. These are open questions of great interest. Many effects of NGF are suppressed by blocking RNA synthesis (Greene and Tischler, 1981), and it will be of interest to determine if the increased number of STX receptors also involves a transcriptional step. It is important to note that the increased excitability of PC12 cells in response to NGF takes several days to develop (Dichter et al., 1977), suggesting that slow metabolic processes are indeed involved. 
Are the few receptors detected in these experiments responsible for the effects of veratridine on PC12 cells? It has been demonstrated that veratridine stimulates the release of endogenous catecholamine stores from $\mathrm{PC} 12$ cells (Greene and Rein, 1977). This led to the suggestion that $\mathrm{PC} 12$ cells must contain at least some $\mathrm{Na}^{+}$channels. Studies of veratridine-induced $\mathrm{Na}^{+}$fluxes in PC12 cells (Stallcup, 1979) also demonstrated that the $\mathrm{Na}^{+}$flux in these cells can be stimulated by veratridine and scorpion venom and that these effects are blocked by TTX. An obvious question is whether veratridine is acting on the few channels detected by the STX binding experiments or if, in addition to these, there are also channels which are not excitable but are responsive to veratridine. If these channels are much less sensitive to TTX and STX, they would not be detected by our binding experiments. Such channels have been described in a nonexcitable cell line derived from a rat brain tumor (Romey et al., 1979) and might be related to the "TTX-insensitive" channels observed in other tissues. Measurements of sodium fluxes in PC12 cultures and of the TTX sensitivity of such fluxes should help clarify if such channels exist in PC12 cells and should indicate what the effects of NGF on these channels might be.

Distribution of STX receptors on the cell. As shown in Table I, cells from which neurites have been sheared mechanically have fewer STX binding sites than those with long processes. This suggests that sodium channels are present both on the cell bodies and on the processes of NGF-treated cells.

\section{References}

Adrian, R. H. (1975) Conduction velocity and gating current in the squid giant axon. Proc. R. Soc. Lond. (Biol.) 189: 81-86.

Agnew, W., S. R. Levinson, J. S. Brabson, and M. A. Raftery (1978) Purification of the tetrodotoxin-binding component associated with the voltage-sensitive sodium channels from Electrophorus electricus electroplax membranes. Proc. Natl. Acad. Sci. U. S. A. 75: 2606-2610.

Bocchini, V., and P. U. Angeletti (1969) The nerve growth factor: Purification as a 30,000 -molecular-weight protein. Proc. Natl. Acad. Sci. U. S. A. 64: 787-794.

Catterall, W. A. (1975) Cooperative activation of the action potential $\mathrm{Na}^{+}$ionophore by neurotoxins. Proc. Natl. Acad. Sci. U. S. A. 72: 1782-1786.

Catterall, W., and S. C. Morrow (1978) Binding of saxitoxin to electrically excitable neuroblastoma cells. Proc. Natl. Acad. Sci. U. S. A. 75: 218-222.

Cuervo, L. A., and W. J. Adelman (1970) Equilibrium and kinetic properties of the interaction between tetrodotoxin and the excitable membrane of the squid giant axon. J. Gen. Physiol. 55: 309-355.

Dichter, M. A., A. S. Tischler, and L. A. Greene (1977) Nerve growth factor-induced change in electrical excitability and acetylcholine sensitivity of a rat pheochromocytoma cell line. Nature 268: 501-504.
Greene, L. A. (1977) A quantitative bioassay for nerve growth factor (NGF) activity employing a clonal pheochromocytoma cell line. Brain Res. 133: 350-353.

Greene, L. A., and G. Rein (1977) Release, storage and uptake of catecholamines by a clonal cell line of nerve growth factor (NGF) responsive pheochromocytoma cells. Brain Res. 129: 274-283.

Greene, L. A., and A. S. Tischler (1976) Establishment of a noradrenergic clonal line of rat adrenal pheochromocytoma cells which respond to nerve growth factor. Proc. Natl. Acad. Sci. U. S. A. 73: 2121-2128.

Greene, L. A., and A. S. Tischler (1981) PC12 pheochromocytoma cells in neurobiological research. In Advances in Cellular Neurobiology, S. Federoff and L. Hertz, eds., Vol. 3, pp. 373-414, Academic Press, New York.

Henderson, R., J. M. Ritchie, and G. Strickhartz (1973) The binding of labelled saxitoxin to the sodium channels in nerve membranes. J. Physiol. (Lond.) 235: 783-804.

Hodgkin, A. L. (1975) The optimum density of sodium channels in an unmyelinated nerve. Philos. Trans. R. Soc. Lond. (Biol.) 270: $297-300$.

Hodgkin, A. L., and A. F. Huxley (1952) A quantitative description of membrane current and its application to conduction and excitation in nerve. J. Physiol. (Lond.) 117: 500-544.

Keynes, R. D., F. Bezanilla, E. Rojas, and R. E. Taylor (1975) The rate of action of tetrodotoxin on sodium conductance in the squid giant axon. Philos. Trans. R. Soc. Lond. (Biol.) 270: $365-375$.

Krueger, B. K., R. W. Ratzlaff, G. R. Strichartz, and M. P. Blaustein (1979) Saxitoxin binding to synaptosomes, membranes and solubilized binding sites from rat brain. J. Membr. Biol. 50: 287-310.

Letourneau, P. C. (1975) Possible roles for cell to substratum adhesion in neuronal morphogenesis. Dev. Biol. 44: 77-91.

Lowry, O. H., N. J. Rosebrough, A. L. Farr, and R. J. Randall (1951) Protein measurement with the Folin phenol reagent. J. Biol. Chem. 193: 265-275.

Narahashi, T. (1974) Chemicals as tools in the study of excitable membranes. Physiol. Rev, 54: 813-889.

O'Lague, P. H., and S. L. Huttner (1980) Physiological and morphological studies of rat pheochromocytoma cells (PC12) chemically fused and grown in culture. Proc. Natl. Acad. Sci. U. S. A. 77: 1701-1705.

Ritchie, J. M., and R. B. Rogart (1977) The binding of saxitoxin and tetrodotoxin to excitable tissue. Rev. Physiol. Biochem. Pharmacol. 79: 1-50.

Ritchie, J. M., K. B. Rogart, and G. K. Strichartz (1976) A new method for labelling saxitoxin and its binding to non-myelinated fibers of the rabbit vagus, lobster walking leg and garfish olfactory nerves. J. Physiol. (Lond.) 261: 477-494.

Romey, G., Y. Jacques, H. Schweitz, M. N. Fosset, and M. Lazdunski (1979) The sodium channel in non-impulsive cells. Interaction with specific neurotoxins. Biochim. Biophys. Acta 556: 344-353.

Stallcup, W. B. (1979) Sodium and calcium fluxes in a clonal nerve cell line. J. Physiol. (Lond.) 286: 525-540.

Ulbricht, W. (1969) The effect of veratridine on excitable membranes of nerve and muscle. Ergeb. Physiol. Biol. Chem. Exp. Pharmakol. 61: 18-71. 